Article

\title{
Trichoderma Contributes to the Germination and Seedling Development of Açaí Palm
}

\author{
Bruno Fróes Campos $\mathbb{D}^{\circledR}$, Anselmo Junior Corrêa Araújo $@$, Cristina Aledi Felsemburgh, \\ Thiago Almeida Vieira *D and Denise Castro Lustosa * \\ Institute of Biodiversity and Forests, Federal University of Western of Pará, Santarém 68035-100, Brazil; \\ camposflorestal@hotmail.com (B.F.C.); anselmojunior.stm@gmail.com (A.J.C.A.); crisalefel@gmail.com (C.A.F.) \\ * Correspondence: thiago.vieira@ufopa.edu.br (T.A.V.); denise.lustosa@ufopa.edu.br (D.C.L.)
}

Received: 1 August 2020; Accepted: 1 October 2020; Published: 3 October 2020

check for updates

\begin{abstract}
The application of Trichoderma fungus can be used to obtain seedlings of higher quality for plantations. The objective of this study was to evaluate the effects of Trichoderma isolates on the germination and initial growth of açaí seedlings. Two trials were set up. In the laboratory, the seeds were inoculated in suspensions prepared with each of the isolates for $24 \mathrm{~h}$, and they were arranged in trays containing filter paper in a completely randomized design with five replicates containing 50 seeds each. For the control, the seeds were submerged only in water. Part of the seedlings resulting from seeds treated and not treated with Trichoderma were transferred to bags containing forest soil and were submitted to seven modes of application of Trichoderma and kept in a nursery. The speed of germination and hypocotyl were not influenced by the biological treatment. The application of the different Trichoderma isolates positively influenced the height, collar diameter, number of leaves, root size, leaf area and root, and aerial part dry mass of the açaí seedlings. The application of the Trichoderma isolate TAM01 on the preplanting substrate and biweekly applications on the postplanting substrate was the combination that most positively influenced the development of açai seedlings.
\end{abstract}

Keywords: fungus; Euterpe oleracea; biostimulants; growth promotion; Amazonia

\section{Introduction}

Euterpe oleracea Mart. (açaí) is a palm that can reach about $20 \mathrm{~m}$ in height, growing preferably in wetlands and being easily found near riverbanks; and it occurs in the entire northern region of Brazil and neighboring countries, such as Venezuela and Guianas [1]. Açaí palm has experienced a great increase in demand in the past four decades, including national and international expansion since the 1990's [2]. The growth in açaí consumption in the world can have positive and negative impacts on collecting communities, the rural landscape, and forest ecosystems, becoming an agro-industrial crop [3] due to an increase in açaí plantations [2].

In Brazil, the state of Pará is the largest producer of açaí and also notably the main producer in the world, growing $27.35 \%$ in 2015 as a result of the application of new management methods and new cultivation technologies [4]. These significant changes in the traditional system of açaizais (açaí plantations) management have associated environmental risks, such as: change in landscape configuration, leading towards homogenization and extinction of other species, including species that protect floodplain border areas; and loss of productive diversity characteristic of riverine family-based farming [5].

Due to the expansion of plantation of açaí, technical information has been used for increased economic output, such as application of herbicides applied postemergence at different stages of the main crop aiming to overcome the competition from weeds, given the initial slow growth of this palm [6]. The main form of propagation of açaí is by means of seeds, although it can also be done 
by the removal of the tillers that appear at the plant base [7]. However, the removal of tillers that arise spontaneously for propagation is recommended only when a reduced number of seedlings is desired [8].

One of the alternatives that can be used to obtain clean seedlings of higher quality for the plantations is the application of the biostimulant microorganism. Its use has provided significant increases in the percentage and early germination, in the dry weight, and in the height of several plants [9].

Among the biostimulant fungi, there are species of Trichoderma. Its use is an interesting strategy for integrated and sustainable management in agricultural cultures [10]. Trichoderma species are also capable of acting as biostimulants of root growth by promoting root development through phytohormones, and thus improve nutrient assimilation, increasing resistance to biotic factors [11].

Seed treatment with Trichoderma can induce short- and long-term improvements in seeds and subsequent plant performance; however, little is known about the initiation of seed interactions with Trichoderma spp., and these interactions are important as it has been shown that seeds respond positively to treatment with Trichoderma harzianum when exposed to physiological, biotic, or abiotic stresses [12].

On the other hand, there is still a low applicability of products based on Trichoderma in Brazil, and one of the justifications for this is the limited availability of commercial products legally registered in the Ministry of Agriculture, Livestock, and Supply (MAPA) [13] with respect to chemicals.

For the species E. oleracea, four isolates of Trichoderma and a mix of this fungus were observed to promote growth and relative accumulation of chlorophyll, and this inoculation could contribute to the sustainable management of the production of açaí seedlings in nurseries for commercial production [14].

The efficient exploitation of the biocontrol and biostimulation capacities of Trichoderma will depend on the ability to select the best isolates and to establish the best conditions of use, generating many possibilities for the application of this fungus in the production of seeds and seedlings [15].

Thus, the objective of this work was to evaluate the effect of five isolates of Trichoderma spp. in different application modes on the germination and growth promotion of E. oleracea seedlings under laboratory and nursery conditions.

\section{Materials and Methods}

The species E. oleracea was selected because of its importance for different populations of the Amazon region and because of its current high consumption all over Brazil and other countries, indicating its economic potential. Açaí fruits were obtained from five matrices of native açaizal (açaí cultivation), located in the Agroextractivist Settlement Project (PAE), Eixo Forte, in the Santa Luzia community in the municipality of Santarém, Brazil. These plants are native (not cultivar). After collecting, they were passed through the process of immersion in hot water and maceration to remove the pulp.

Two trials were carried out: (1) under laboratory conditions from February to March 2016 (average temperature of $25^{\circ} \mathrm{C} \pm 2{ }^{\circ} \mathrm{C}$ ); and (2) in a nursery covered with $50 \%$ shading from February to December 2016 (temperature varied between $32{ }^{\circ} \mathrm{C}$ and $22{ }^{\circ} \mathrm{C}$ ). Both of them were set up at the Institute of Biodiversity and Forests, Federal University of Western Pará-Ufopa, in Santarém.

The climate of the region according to the Köppen classification is of Am type [16], presenting for the year 2016 an average precipitation value of approximately $1888 \mathrm{~mm}$, relative humidity of $88 \%$ and average maximum and minimum temperature of $32{ }^{\circ} \mathrm{C}$ and $22{ }^{\circ} \mathrm{C}$ for this same year, respectively.

The study used five isolates in total: three isolates of Trichoderma spp. (TAM01, TAM02, and TAM03) and two isolates of Trichoderma sp. (Tc and Tce), from Amazonian soils, Brazil. For assembly of the tests and subsequent applications, the mass production of the fungi in parboiled rice was performed.

The choice of these Trichoderma isolates was based on promising preliminary results and for being of regional origin, and therefore being adapted to the climate conditions of the study site. 


\subsection{Germination of açaí Seeds}

The açaí seeds were washed in distilled and sterilized water and submitted to biological treatment

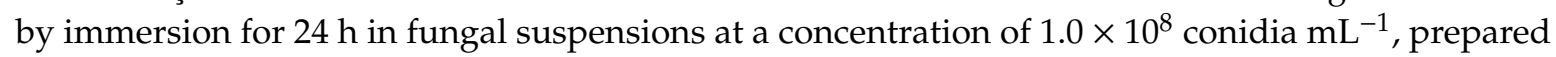
with each of the Trichoderma isolates. The control treatment consisted of immersing the seeds only in distilled and sterilized water for the same period. After the inoculation, the seeds were deposited in plastic trays containing two sheets of filter paper moistened with distilled and sterilized water and taken to the germination chamber. The seed trays were stored at $25 \pm 2{ }^{\circ} \mathrm{C}$ and $12 \mathrm{~h} \mathrm{light} \mathrm{photoperiod}$. The experimental design was completely randomized with five replicates, having 40 seeds per replicate and a total of 1200 seeds.

The following variables were evaluated: (a) speed of germination rate index (SG) by counting the number of germinated seeds per day until its stabilization. According to Martins et al. [17], the germination reached stabilization when the same number of germinated seeds were obtained in three consecutive counts. The SG was calculated at the end according to the formula of Maguire [18]; (b) germination by counting the number of seeds germinated after stabilization, calculating the germination percentage of the seeds; and, (c) hypocotyl length by measuring these structures with digital caliper at 7 days after the germination stabilization.

\subsection{Initial Development of açaí Seedlings}

The effect of the biological treatment on the initial development of açaí seedlings was evaluated using the five Trichoderma isolates under three application modes (seeds, preplanting substrate, and postplanting substrate applications) and in combinations between them, resulting in the following treatments:

(1) application of Trichoderma isolates in seeds;

(2) application of Trichoderma isolates on the preplanting substrate;

(3) biweekly applications of suspensions of Trichoderma isolates on the postplanting substrate;

(4) application of Trichoderma isolates in seeds + application of Trichoderma isolates in the preplanting substrate;

(5) application of Trichoderma isolates in seeds + biweekly applications of suspensions of Trichoderma isolates on the postplanting substrate;

(6) application of the Trichoderma isolates to the preplanting substrate + biweekly applications of suspensions of the Trichoderma isolates on the postplanting substrate

(7) application of Trichoderma isolates in seeds + application of Trichoderma isolates in the preplanting substrate + biweekly applications of suspensions of Trichoderma isolates in the postplanting substrate and,

(8) Treatment control (without any application of Trichoderma).

In order to set up the assay, after germination evaluations were completed in the laboratory, both the 40 seedlings resulting from seeds treated with each of the Trichoderma isolates (total of 200 seedlings) and the 160 seedlings resulting from seeds not biologically treated were randomly sampled. Seedlings from Trichoderma-treated seeds were used for treatments 1, 4, 5, and 7, and those from seeds not biologically treated were used for treatments 2, 3, 6, and 8. For all eight treatments, the seedlings were transplanted to polyethylene bags containing forest soil and kept in a nursery with $50 \%$ shading throughout the evaluation period.

The treatments using Trichoderma isolates on the substrate were carried out seven days before transplanting the seedlings by first wetting the substrate and applying $100 \mathrm{~mL}$ of $1.0 \times 10^{8}$ conidia $\mathrm{mL}^{-1}$ suspension of the isolates of Trichoderma to $1.5 \mathrm{~kg}$ of soil. The determination and calibration of the suspension concentration was performed in a hemacytometer according to Alfenas and Mafia [19].

The treatments with biweekly applications of suspensions of the Trichoderma isolates in the postplanting soil started at 15 days after transplanting and consisted of the application of $100 \mathrm{~mL}$ of the 
fungal suspensions, using the same concentration as the application to the substrate before planting. During the 132 days of the test, 15 applications of Trichoderma isolates were performed.

The experimental design was completely randomized in a factorial scheme $(7 \times 5+1)$ with seven modes of application of Trichoderma $\times$ five Trichoderma isolates + a control treatment with 10 replicates and one plant per replicate, making a total of 36 treatments and 360 seedlings. During the period of stay in the nursery (132 days), the plants were irrigated daily.

The following variables were evaluated: (a) height of the seedlings by measuring the base of the plant to the highest leaf petiole with a millimeter ruler; (b) stem diameter by measuring the collar diameter with a digital caliper during the first three months at biweekly intervals, and after that period, they were measured monthly. At the end of the trial, the following were evaluated: (a) number of leaves, counting the total number of leaves per seedling; (b) length of the root system, removing the seedlings from the bags for measurement with the aid of a millimeter ruler; (c) leaf area by the WinDIAS image analysis system (model W-C110-PC, Delta-T Devices Ltda., Cambridge, UK); and (d) dry mass of aerial part and root system, where after separation of these parts, the roots were washed for removal of the adhered soil, and both parts were placed separately in a well-identified paper bag, taken to a greenhouse with forced circulation of air at $60{ }^{\circ} \mathrm{C}$ for $72 \mathrm{~h}$, and weighed at the end of that period.

\subsection{Data Analysis}

The germination data were transformed to $\operatorname{arcsen} \sqrt{ } \mathrm{x} / 100$. All data were analyzed by the statistical software Assistat ${ }^{\circledR}$ Version 7.7 [20]. For the germination data obtained in the laboratory, the Tukey test was performed after the analysis of variance. For the developmental data of the seedlings from the nursery test, the treatment averages were analyzed by ANOVA two-way, with Trichoderma isolates and application modes as sources of variability. The Dunnett test was applied to compare the means of the groups treated with the control, and the Tukey test was used to compare the means between the treated groups, both at $5 \%$ probability. For better visualization of the treatments, germination data were used in percentage, as shown in the Table 1.

Table 1. Percentage and standard deviation of germination, speed of germination (SG), and hypocotyl length of untreated açaí (Euterpe oleracea) seeds treated with different Trichoderma spp. isolates.

\begin{tabular}{cccc}
\hline Treatment & Germination (\%) & SG & Hypocotyl (mm) \\
\hline Control & $95.0 \pm 4.7 \mathrm{~b}$ & $28.4 \pm 2.9 \mathrm{ab}$ & $18.4 \pm 6.9 \mathrm{ab}$ \\
TAM01 & $98.5 \pm 2.2 \mathrm{ab}$ & $28.4 \pm 1.1 \mathrm{ab}$ & $16.7 \pm 5.4 \mathrm{ab}$ \\
TAM02 & $97.0 \pm 2.7 \mathrm{ab}$ & $28.9 \pm 1.1 \mathrm{a}$ & $18.2 \pm 6.3 \mathrm{ab}$ \\
TAM03 & $100.0 \pm 0.0 \mathrm{a}$ & $26.4 \pm 1.83 \mathrm{~b}$ & $16.5 \pm 6.4 \mathrm{~b}$ \\
TC & $97.0 \pm 2.1 \mathrm{ab}$ & $26.9 \pm 2.25 \mathrm{ab}$ & $19.1 \pm 9.4 \mathrm{a}$ \\
Tce & $96.0 \pm 1.4 \mathrm{~b}$ & $28.4 \pm 1.33 \mathrm{ab}$ & $17.6 \pm 5.9 \mathrm{ab}$ \\
\hline CV $(\%)$ & 6.6 & 3.6 & 6.4
\end{tabular}

$\mathrm{CV}$ : coefficient of variation. Means followed by the same letters in the columns do not differ from each other by the Tukey test $(p \leq 0.05)$.

\section{Results}

\subsection{Germination of açaí Seeds}

Açaí seeds started germination after six days, and they reached stabilization at 28 days after assay setup. There was a significant difference for all analyzed variables (Table 1 ). In all treatments, germination was greater than $95 \%$. However, only the T. asperellum-TAM03 isolate obtained a higher germination rate than the control treatment (Table 1). None of the Trichoderma isolates increased the SG in relation to the control.

In the evaluation of the initial growth of açaí seedlings, none of the Trichoderma isolates increased the hypocotyl length in relation to the control. 


\subsection{Initial Development of açaí Seedlings}

Two-way ANOVA showed there was a significant effect of the main treatment isolated from Trichoderma for height, stem diameter, length of root and root dry mass, as well as the main treatment modes of application for the variables analyzed, except for number of leaves. In the Trichoderma $\times$ modes of application interaction, only the leaf area variable was not significant (Table 2, Figure 1).

Table 2. Results of repeated measures ANOVA two-way testing the effect of isolates of Trichoderma and modes of application on açaí seedlings growth.

\begin{tabular}{cccccccc}
\hline Source of Variation & $\begin{array}{c}\text { Height } \\
(\mathbf{c m})\end{array}$ & $\begin{array}{c}\text { Collar Diameter } \\
(\mathbf{c m})\end{array}$ & $\begin{array}{c}\text { Number of } \\
\text { Leaves }\end{array}$ & $\begin{array}{c}\text { Leaf Area } \\
(\mathbf{c m})\end{array}$ & $\begin{array}{c}\text { Root } \\
(\mathbf{c m})\end{array}$ & $\begin{array}{c}\text { Root DM } \\
(\mathbf{g})\end{array}$ & $\begin{array}{c}\text { Aerial Part DM } \\
(\mathbf{g})\end{array}$ \\
\hline \multirow{2}{*}{ Trichoderma } & $\mathrm{F}=7.4$, & $\mathrm{F}=12.6$, & $\mathrm{F}=1.4$, & $\mathrm{F}=1.9$, & $\mathrm{F}=16.4$, & $\mathrm{F}=2.0$, & $\mathrm{F}=3.8$, \\
& $p<0.001$ & $p<0.001$ & $p=0.214$ & $p<0.103$ & $p<0.001$ & $p=0.084$ & $p=0.005$ \\
Modes of application & $\mathrm{F}=5.2$, & $\mathrm{F}=37.9$, & $\mathrm{F}=2.3$, & $\mathrm{F}=3.4$, & $\mathrm{F}=7.3$, & $\mathrm{F}=3.4$, & $\mathrm{F}=3.4$, \\
& $p<0.001$ & $p<0.001$ & $p<0.028$ & $p=0.001$ & $p<0.001$ & $p=0.001$ & $p=0.001$ \\
Trichoderma $\times$ Modes & $\mathrm{F}=5.9$, & $\mathrm{F}=9.3$, & $\mathrm{F}=2.0$, & $\mathrm{F}=1.8$, & $\mathrm{F}=3.2$, & $\mathrm{F}=2.5$, & $\mathrm{F}=2.3$, \\
& $p<0.001$ & $p<0.001$ & $p<0.002$ & $p=0.007$ & $p<0.001$ & $p<0.001$ & $p<0.001$ \\
\hline
\end{tabular}

DM: dry mass.

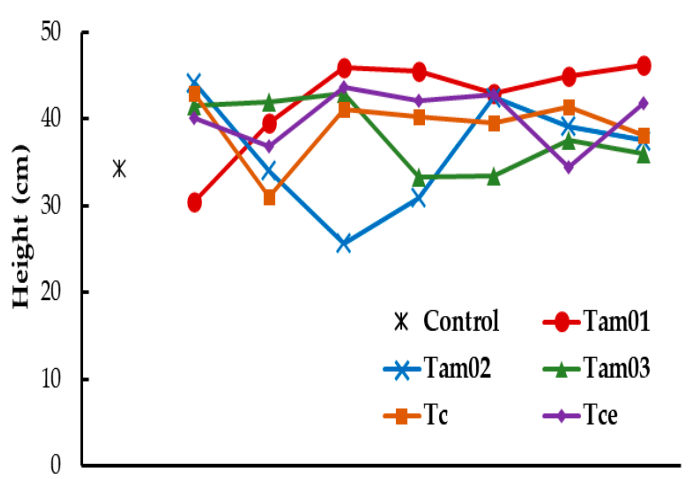

M.A.0 M.A.1 M.A. 2 M.A.3 M.A.4 M.A.5 M.A.6 M.A.7

Modes of application of Trichoderma

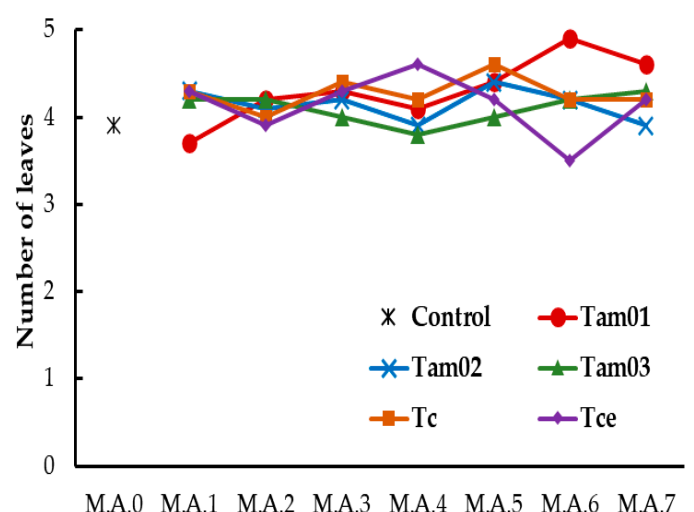

Modes of application of Trichoderma
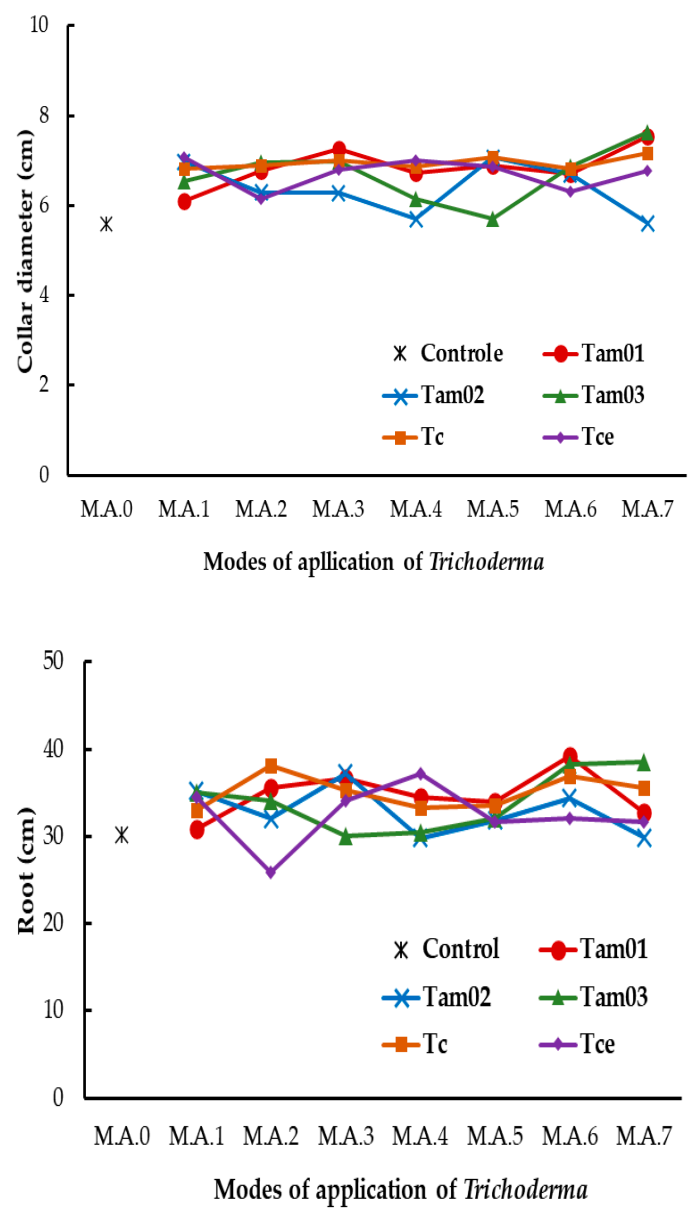

Figure 1. Cont. 

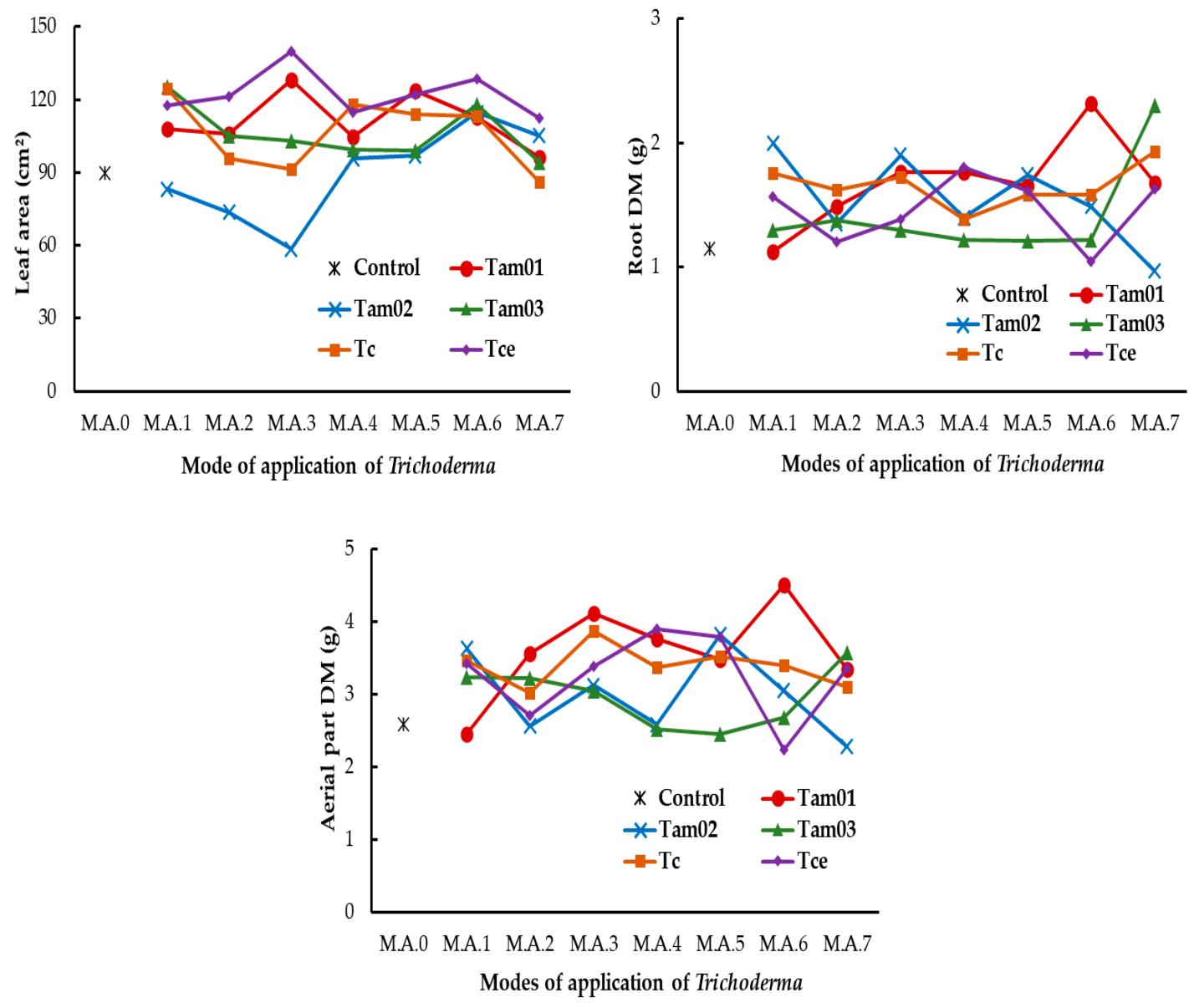

Figure 1. Average of height, collar diameter, number of leaves, root length, leaf foliar, root dry mass (DM), and aerial part dry mass of açaí seedlings submitted to different modes of application of Trichoderma isolates. M.A.0: without any application of Trichoderma (treatment control). M.A.1: application of Trichoderma isolates in seeds; M.A.2: application of Trichoderma isolates on the preplanting substrate; M.A.3: biweekly applications of suspensions of Trichoderma isolates on the postplanting substrate; M.A.4: application of Trichoderma isolates in seeds + application of Trichoderma isolates in the preplanting substrate; M.A.5: application of Trichoderma isolates in seeds + biweekly applications of suspensions of Trichoderma isolates on the postplanting substrate; M.A.6: application of the Trichoderma isolates to the preplanting substrate + biweekly applications of suspensions of the Trichoderma isolates on the postplanting substrate; and M.A.7: application of Trichoderma isolates in seeds + application of Trichoderma isolates in the preplanting substrate + biweekly applications of suspensions of Trichoderma isolates in the postplanting substrate.

There was a significant difference in height, collar diameter, and leaf area, based on the Dunnett test. The height of the plants in the treatments that differed from the control ranged from $42.8 \mathrm{~cm}$ to $46.2 \mathrm{~cm}$ (Table 3), which corresponded to an increase of $24.6 \%$ and $33.9 \%$, respectively, for this variable. 
Table 3. Average and standard deviation of height, collar diameter, number of leaves, root length, leaf area, root and aerial part dry mass of Açaí (Euterpe oleracea) seedlings submitted to different modes of application of five Trichoderma spp. isolates at 132 days after planting.

\begin{tabular}{|c|c|c|c|c|c|c|c|}
\hline Treatments & $\begin{array}{l}\text { Height } \\
(\mathrm{cm})\end{array}$ & $\begin{array}{l}\text { Collar Diameter } \\
(\mathrm{cm})\end{array}$ & $\begin{array}{l}\text { Number of } \\
\text { Leaves }\end{array}$ & $\begin{array}{l}\text { Root } \\
(\mathrm{cm})\end{array}$ & $\begin{array}{l}\text { Leaf Area } \\
\left(\mathrm{cm}^{2}\right)\end{array}$ & $\begin{array}{l}\text { Root DM } \\
\text { (g) }\end{array}$ & $\begin{array}{l}\text { Aerial Part DM } \\
\text { (g) }\end{array}$ \\
\hline TAM01 applied to seeds & $30.4 \pm 3.8^{\mathrm{ns}}$ & $6.1 \pm 0.6^{\mathrm{ns}}$ & $3.7 \pm 0.6^{\mathrm{ns}}$ & $30.9 \pm 6.3^{\mathrm{ns}}$ & $107.9 \pm 28.5^{\mathrm{ns}}$ & $1.1 \pm 0.3^{\mathrm{ns}}$ & $2.5 \pm 0.7^{\mathrm{ns}}$ \\
\hline TAM01 applied to preplanting substrate & $39.6 \pm 10.3^{\mathrm{ns}}$ & $6.7 \pm 1.0^{* *}$ & $4.2 \pm 0.6^{\mathrm{ns}}$ & $35.6 \pm 6.4^{\mathrm{ns}}$ & $105.8 \pm 59.3^{\mathrm{ns}}$ & $1.5 \pm 0.5^{\mathrm{ns}}$ & $3.6 \pm 1.5^{\mathrm{ns}}$ \\
\hline TAM01 applied biweekly to postplanting substrate & $46.0 \pm 7.9^{*}$ & $7.2 \pm 0.9 * *$ & $4.3 \pm 0.6^{\mathrm{ns}}$ & $36.6 \pm 7.4^{\mathrm{ns}}$ & $128.2 \pm 46.8^{* *}$ & $1.8 \pm 0.4^{\mathrm{ns}}$ & $4.1 \pm 1.0^{* *}$ \\
\hline TAM01 applied to seeds + preplanting substrate & $45.5 \pm 6.3^{*}$ & $6.7 \pm 0.9^{* *}$ & $4.1 \pm 0.5^{\mathrm{ns}}$ & $34.5 \pm 4.5^{\mathrm{ns}}$ & $104.5 \pm 40.1$ ns & $1.8 \pm 0.6^{\mathrm{ns}}$ & $3.8 \pm 1.0^{\mathrm{ns}}$ \\
\hline TAM01 applied to seeds + biweekly on postplanting substrate & $42.9 \pm 8.8^{*}$ & $6.9 \pm 1.2^{* *}$ & $4.4 \pm 0.5^{\mathrm{ns}}$ & $34.0 \pm 7.6^{\mathrm{ns}}$ & $123.8 \pm 45.1^{* *}$ & $1.7 \pm 0.7^{\mathrm{ns}}$ & $3.5 \pm 1.2^{\mathrm{ns}}$ \\
\hline TAM01 applied to preplanting substrate + biweekly to substrate & $44.9 \pm 7.6^{*}$ & $6.7 \pm 1.4^{* *}$ & $4.9 \pm 0.7^{* *}$ & $39.2 \pm 8.7 * *$ & $112.6 \pm 37.8^{\mathrm{ns}}$ & $2.3 \pm 1.0^{* *}$ & $4.5 \pm 1.4 * *$ \\
\hline TAM01 applied to seeds + substrate + biweekly to substrate & $46.2 \pm 9.5 *$ & $7.5 \pm 1.4^{* *}$ & $4.6 \pm 0.5^{\mathrm{ns}}$ & $32.7 \pm 10.0^{\mathrm{ns}}$ & $96.2 \pm 24.1^{\mathrm{ns}}$ & $1.7 \pm 1.0^{\mathrm{ns}}$ & $3.3 \pm 1.6^{\mathrm{ns}}$ \\
\hline TAM02 applied to seeds & $44.2 \pm 7.7^{*}$ & $7.0 \pm 1.1^{* *}$ & $4.3 \pm 0.7^{\mathrm{ns}}$ & $35.2 \pm 8.4^{\mathrm{ns}}$ & $83.2 \pm 22.7^{\mathrm{ns}}$ & $2.0 \pm 0.8^{\mathrm{ns}}$ & $3.6 \pm 1.5^{\mathrm{ns}}$ \\
\hline TAM02 applied to preplanting substrate & $34.0 \pm 7.3^{\mathrm{ns}}$ & $6.3 \pm 1.2 * *$ & $4.1 \pm 0.8^{\mathrm{ns}}$ & $32.0 \pm 5.1^{\mathrm{ns}}$ & $73.7 \pm 39.2^{\mathrm{ns}}$ & $1.3 \pm 0.5^{\mathrm{ns}}$ & $2.6 \pm 1.0^{\mathrm{ns}}$ \\
\hline TAM02 applied biweekly to postplanting substrate & $25.7 \pm 6.1 *$ & $6.3 \pm 1.1^{* *}$ & $4.2 \pm 1.0^{\mathrm{ns}}$ & $37.2 \pm 9.8^{\mathrm{ns}}$ & $58.6 \pm 17.8^{* *}$ & $1.9 \pm 0.9^{\mathrm{ns}}$ & $3.1 \pm 1.1^{\mathrm{ns}}$ \\
\hline TAM02 applied to seeds + preplanting substrate & $30.9 \pm 4.5^{\mathrm{ns}}$ & $5.7 \pm 0.5^{\mathrm{ns}}$ & $3.9 \pm 0.9^{\mathrm{ns}}$ & $29.8 \pm 1.8^{\mathrm{ns}}$ & $95.7 \pm 19.0^{\mathrm{ns}}$ & $1.4 \pm 0.3^{\mathrm{ns}}$ & $2.6 \pm 0.6^{\mathrm{ns}}$ \\
\hline TAM02 applied to seeds + biweekly on postplanting substrate & $42.5 \pm 6.2 *$ & $7.1 \pm 0.7 * *$ & $4.4 \pm 0.6^{\mathrm{ns}}$ & $31.8 \pm 6.7^{\mathrm{ns}}$ & $96.9 \pm 25.5^{\mathrm{ns}}$ & $1.7 \pm 0.7^{\mathrm{ns}}$ & $3.8 \pm 0.9^{\mathrm{ns}}$ \\
\hline TAM02 applied to preplanting substrate + biweekly to substrate & $39.1 \pm 5.6^{\mathrm{ns}}$ & $6.7 \pm 0.9^{* *}$ & $4.2 \pm 0.5^{\mathrm{ns}}$ & $34.4 \pm 5.1^{\mathrm{ns}}$ & $114.6 \pm 39.5^{\mathrm{ns}}$ & $1.5 \pm 0.6^{\mathrm{ns}}$ & $3.1 \pm 1.0^{\mathrm{ns}}$ \\
\hline TAM02 applied to seeds + substrate + biweekly to substrate & $37.5 \pm 6.8^{\mathrm{ns}}$ & $5.6 \pm 1.1^{\mathrm{ns}}$ & $3.8 \pm 0.5^{\mathrm{ns}}$ & $29.9 \pm 6.3^{\mathrm{ns}}$ & $105.2 \pm 27.9^{\mathrm{ns}}$ & $1.0 \pm 0.4^{\mathrm{ns}}$ & $2.3 \pm 1.0^{\mathrm{ns}}$ \\
\hline TAM03 applied to seeds & $41.6 \pm 6.4^{\mathrm{ns}}$ & $6.5 \pm 1.2 * *$ & $4.2 \pm 0.6^{\mathrm{ns}}$ & $35.0 \pm 6.1^{\mathrm{ns}}$ & $125.4 \pm 43.7^{* *}$ & $1.3 \pm 0.3^{\mathrm{ns}}$ & $3.2 \pm 0.8^{\mathrm{ns}}$ \\
\hline TAM03 applied to preplanting substrate & $41.9 \pm 5.5^{\mathrm{ns}}$ & $6.9 \pm 1.0^{* *}$ & $4.2 \pm 0.5^{\mathrm{ns}}$ & $34.1 \pm 7.3^{\mathrm{ns}}$ & $105.2 \pm 33.0^{\mathrm{ns}}$ & $1.4 \pm 0.6^{\mathrm{ns}}$ & $3.2 \pm 1.1^{\mathrm{ns}}$ \\
\hline TAM03 applied biweekly to postplanting substrate & $43.0 \pm 8.4 *$ & $6.9 \pm 1.1^{* *}$ & $4.0 \pm 0.6^{\mathrm{ns}}$ & $30.0 \pm 4.1^{\mathrm{ns}}$ & $103.2 \pm 44.7^{\mathrm{ns}}$ & $1.3 \pm 0.3^{\mathrm{ns}}$ & $3.1 \pm 0.8^{\mathrm{ns}}$ \\
\hline TAM03 applied to seeds + preplanting substrate & $33.3 \pm 4.9^{\mathrm{ns}}$ & $6.1 \pm 0.9^{\mathrm{ns}}$ & $3.8 \pm 0.8^{\mathrm{ns}}$ & $30.5 \pm 5.3^{\text {ns }}$ & $99.2 \pm 38.2^{\mathrm{ns}}$ & $1.2 \pm 0.5^{\mathrm{ns}}$ & $2.5 \pm 0.8^{\mathrm{ns}}$ \\
\hline TAM03 applied to seeds + biweekly on postplanting substrate & $33.4 \pm 6.9^{\mathrm{ns}}$ & $5.7 \pm 0.9^{\mathrm{ns}}$ & $4.0 \pm 0.7^{\mathrm{ns}}$ & $32.1 \pm 6.4^{\mathrm{ns}}$ & $99.0 \pm 28.3^{\mathrm{ns}}$ & $1.2 \pm 0.7^{\mathrm{ns}}$ & $2.5 \pm 1.1^{\mathrm{ns}}$ \\
\hline TAM03 applied to preplanting substrate + biweekly to substrate & $37.5 \pm 7.0^{\mathrm{ns}}$ & $6.9 \pm 1.2^{* *}$ & $4.2 \pm 0.6^{\mathrm{ns}}$ & $38.3 \pm 9.6^{\mathrm{ns}}$ & $117.8 \pm 41.3^{\mathrm{ns}}$ & $1.2 \pm 0.6^{\mathrm{ns}}$ & $2.7 \pm 1.2^{\mathrm{ns}}$ \\
\hline TAM03 applied to seeds + substrate + biweekly to substrate & $36.0 \pm 6.1^{\mathrm{ns}}$ & $7.6 \pm 1.1^{* *}$ & $4.3 \pm 0.8^{\mathrm{ns}}$ & $38.5 \pm 6.4^{\mathrm{ns}}$ & $94.1 \pm 34.1^{\mathrm{ns}}$ & $2.3 \pm 1.1 * *$ & $3.6 \pm 1.2^{\mathrm{ns}}$ \\
\hline TC applied to seeds & $42.9 \pm 8.0 *$ & $6.8 \pm 1.2 * *$ & $4.3 \pm 0.4^{\mathrm{ns}}$ & $33.0 \pm 4.9^{\mathrm{ns}}$ & $124.4 \pm 52.4^{* *}$ & $1.8 \pm 0.7^{\mathrm{ns}}$ & $3.5 \pm 1.1^{\mathrm{ns}}$ \\
\hline TC applied to preplanting substrate & $31.0 \pm 7.1^{\mathrm{ns}}$ & $6.9 \pm 1.3 * *$ & $4.0 \pm 0.7^{\mathrm{ns}}$ & $38.1 \pm 7.6^{\mathrm{ns}}$ & $96.0 \pm 47.7^{\mathrm{ns}}$ & $1.6 \pm 0.5^{\mathrm{ns}}$ & $3.0 \pm 0.8^{\mathrm{ns}}$ \\
\hline TC applied biweekly to postplanting substrate & $41.1 \pm 7.3^{\mathrm{ns}}$ & $7.0 \pm 1.2 * *$ & $4.4 \pm 0.5^{\mathrm{ns}}$ & $35.3 \pm 6.1^{\mathrm{ns}}$ & $91.5 \pm 38.8^{\mathrm{ns}}$ & $1.7 \pm 0.7^{\mathrm{ns}}$ & $3.9 \pm 1.4^{\mathrm{ns}}$ \\
\hline TC applied to seeds + preplanting substrate & $40.2 \pm 8.2^{\mathrm{ns}}$ & $6.9 \pm 1.1^{* *}$ & $4.2 \pm 0.6^{\mathrm{ns}}$ & $33.3 \pm 6.4^{\mathrm{ns}}$ & $118.1 \pm 32.7^{\mathrm{ns}}$ & $1.4 \pm 0.7^{\mathrm{ns}}$ & $3.4 \pm 1.3^{\mathrm{ns}}$ \\
\hline TC applied to seeds + biweekly on postplanting substrate & $39.5 \pm 10.5^{\mathrm{ns}}$ & $7.1 \pm 1.0^{* *}$ & $4.6 \pm 0.5^{\mathrm{ns}}$ & $33.6 \pm 8.9^{\text {ns }}$ & $114.1 \pm 28.3^{\mathrm{ns}}$ & $1.6 \pm 0.7^{\mathrm{ns}}$ & $3.5 \pm 1.2^{\mathrm{ns}}$ \\
\hline TC applied to preplanting substrate + biweekly to substrate & $41.4 \pm 6.5^{\mathrm{ns}}$ & $6.8 \pm 1.1^{* *}$ & $4.2 \pm 0.5^{\mathrm{ns}}$ & $36.9 \pm 7.7^{\mathrm{ns}}$ & $113.1 \pm 39.4^{\text {ns }}$ & $1.6 \pm 0.6^{\mathrm{ns}}$ & $3.4 \pm 1.2^{\mathrm{ns}}$ \\
\hline TC applied to seeds + substrate + biweekly to substrate & $38.1 \pm 6.2^{\mathrm{ns}}$ & $7.2 \pm 1.1^{* *}$ & $4.2 \pm 0.6^{\mathrm{ns}}$ & $35.6 \pm 5.1^{\mathrm{ns}}$ & $86.0 \pm 31.8^{\mathrm{ns}}$ & $1.9 \pm 1.0^{\mathrm{ns}}$ & $3.1 \pm 1.0^{\mathrm{ns}}$ \\
\hline TCE applied to seeds & $40.1 \pm 6.2^{\mathrm{ns}}$ & $7.1 \pm 0.8^{* *}$ & $4.3 \pm 0.5^{\mathrm{ns}}$ & $34.5 \pm 7.2^{\mathrm{ns}}$ & $117.5 \pm 41.7^{\mathrm{ns}}$ & $1.6 \pm 0.6^{\mathrm{ns}}$ & $3.4 \pm 0.9^{\mathrm{ns}}$ \\
\hline TCE applied to preplanting substrate & $36.9 \pm 7.9^{\mathrm{ns}}$ & $6.1 \pm 1.1^{\mathrm{ns}}$ & $3.9 \pm 0.6^{\mathrm{ns}}$ & $25.9 \pm 4.5^{\mathrm{ns}}$ & $121.2 \pm 40.0^{* *}$ & $1.2 \pm 0.6^{\mathrm{ns}}$ & $2.7 \pm 1.2^{\mathrm{ns}}$ \\
\hline TCE applied biweekly to postplanting substrate & $43.6 \pm 6.7^{*}$ & $6.8 \pm 0.8 * *$ & $4.3 \pm 0.5^{\text {ns }}$ & $34.1 \pm 6.7 \mathrm{~ns}$ & $139.9 \pm 50.1^{* *}$ & $1.4 \pm 0.3^{\mathrm{ns}}$ & $3.4 \pm 0.6^{\mathrm{ns}}$ \\
\hline TCE applied to seeds + preplanting substrate & $42.1 \pm 7.6^{\mathrm{ns}}$ & $7.0 \pm 0.9^{* *}$ & $4.6 \pm 0.5^{\mathrm{ns}}$ & $37.2 \pm 7.6^{\mathrm{ns}}$ & $114.6 \pm 36.6^{\mathrm{ns}}$ & $1.8 \pm 0.6^{\mathrm{ns}}$ & $3.9 \pm 1.0^{\mathrm{ns}}$ \\
\hline TCE applied to seeds + biweekly on postplanting substrate & $42.8 \pm 9.5 *$ & $6.9 \pm 1.4^{* *}$ & $4.2 \pm 0.6^{\mathrm{ns}}$ & $31.7 \pm 8.8^{\mathrm{ns}}$ & $122.0 \pm 30.7^{* *}$ & $1.6 \pm 0.7^{\mathrm{ns}}$ & $3.8 \pm 1.3^{\text {ns }}$ \\
\hline TCE applied to preplanting substrate + biweekly to substrate & $34.4 \pm 6.5^{\mathrm{ns}}$ & $6.3 \pm 1.1^{* *}$ & $3.5 \pm 0.8^{\mathrm{ns}}$ & $32.0 \pm 5.0^{\mathrm{ns}}$ & $128.7 \pm 41.2 *$ & $1.0 \pm 0.5^{\mathrm{ns}}$ & $2.2 \pm 1.1^{\mathrm{ns}}$ \\
\hline TCE applied to seeds + substrate + biweekly to substrate & $41.8 \pm 7.1^{\mathrm{ns}}$ & $6.8 \pm 0.9^{* *}$ & $4.2 \pm 0.4^{\mathrm{ns}}$ & $31.6 \pm 5.2^{\mathrm{ns}}$ & $112.4 \pm 33.4 \mathrm{~ns}$ & $1.6 \pm 0.6^{\mathrm{ns}}$ & $3.4 \pm 1.1^{\mathrm{ns}}$ \\
\hline Control & $34.3 \pm 7.9$ & $5.6 \pm 0.9$ & $3.9 \pm 0.5$ & $30.2 \pm 6.2$ & $89.8 \pm 30.5$ & $1.1 \pm 0.4$ & $2.6 \pm 0.9$ \\
\hline
\end{tabular}

** Significant at the $1 \%$ probability level $(p<0.01) ;{ }^{*}$ significant at the $5 \%$ probability level $(p<0.05)$; ns not significant $(p \geq 0.05)$ by the Dunnett test. TAM01: Trichoderma asperellum;

TAM02: Trichoderma asperellum; TAM03: Trichoderma asperellum; Tc: Trichoderma sp.; Tce: Trichoderma sp.; and DM: dry mass. 
Trichoderma asperellum-TAM01 isolate increased the height of the seedlings in five of the seven application modes used (Table 3). This shows that if the commercial or ecological parameter of interest is height, one must invest in treatments that add this fungus to the seed or substrate.

The fungus T. asperellum-TAM02 applied to the seeds, biweekly in the postplanting substrate and in the combination of these two forms, also provided an increase in the height of the açaí seedlings. On the other hand, the isolates T. asperellum-TAM03, Trichoderma sp.-Tc, and Trichoderma sp.-Tce increased this variable in only one of the application modes under the following: applications performed on the seeds; application biweekly on the postplanting substrate, and application biweekly on the postplanting substrate, respectively (Table 3 ).

Regarding the collar diameter, 29 of the 34 evaluated treatments differed from the control by the Dunnett test (Table 3). The increase in this structure varied from $16 \%$ to $43.4 \%$. All tested Trichoderma isolates increased the collar diameter in at least four application modes, T. asperellum-TAM01 did not increase this variable when applied to seeds, and Trichoderma sp.-Tc increased the diameter in relation to the control, regardless of the mode of application used (Table 3).

At least one of the modes of application of all Trichoderma isolates influenced the leaf area of the seedlings. The treatments that differed from the control had a mean leaf area ranging from $121.2 \mathrm{~cm}^{2}$ to $139.9 \mathrm{~cm}^{2}$ (Table 3), which corresponded to an increase of $35 \%$ and $55.8 \%$, respectively.

Of the nine treatments that differed from the control to leaf area, four were from applications with the Trichoderma sp.-Tce. This biweekly application of fungus to the postplanting substrate provided the highest average leaf area $\left(139.9 \mathrm{~cm}^{2}\right)$ and was followed by its combined application on the preplanting substrate + biweekly applications on the postplanting substrate (Table 3).

Only TAM01 applied to preplanting substrate and biweekly to substrate provided an increase in the root length. This treatment and the TAM03 applied to seeds, substrate preplanting, and biweekly to substrate provided significant difference between the control, using Dunnett's test, for root dry mass (Table 3). The fungus TAM01 provided increase in the aerial part dry mass under two types of application: applied biweekly to postplanting substrate and preplanting substrate + biweekly to substrate.

The increases observed in the height, aerial part diameter, and leaf area of the açaí seedlings when compared to the control treatment, provided by the applications of T. asperellum-TAM01 (biweekly in the postplanting substrate and also in the combination of seeds + biweekly in the postplanting), T. asperellum-TAM02 (biweekly on the postplanting substrate), and by Trichoderma sp.-Tc (seeds), were attributed to a larger leaf area.

In relation to the interaction between the factors (Trichoderma spp. $\times$ mode of application), it was observed that there was a significant difference between treatments for all variables analyzed by Tukey's test (height, collar diameter, leaf number, leaf area, root length, and dry mass of the aerial part and radicle system).

For the height of the seedlings, when the fungi were tested in seed treatment, the lowest height was observed in the application of T. asperellum-TAM01. However, the applications of T. asperellum-TAM01 in the combined three application modes (seeds + substrate + biweekly applications) resulted in higher plant height, not differing only from Trichoderma sp.-Tce (Table 4). 
Table 4. Average height of the Açaí (Euterpe oleracea) plants submitted to different modes of application of five Trichoderma spp. isolates at 132 days after planting.

\begin{tabular}{cccccccc}
\hline \multirow{2}{*}{$\begin{array}{c}\text { Trichoderma } \\
\text { Isolates }\end{array}$} & \multicolumn{7}{c}{ Mverage Height (cm) } \\
\cline { 2 - 8 } & TS & AS & AQ & TS + AS & TS + AQ & AS + AQ & S + AS + AQ \\
\cline { 2 - 7 } & $30.4 \mathrm{bB}$ & $39.6 \mathrm{abA}$ & $46.0 \mathrm{aA}$ & $45.5 \mathrm{aA}$ & $42.9 \mathrm{aA}$ & $44.9 \mathrm{aA}$ & $46.2 \mathrm{aA}$ \\
TAM01 & $44.2 \mathrm{aA}$ & $34.1 \mathrm{bcBC}$ & $25.7 \mathrm{bD}$ & $30.9 \mathrm{cCD}$ & $42.5 \mathrm{aA}$ & $39.1 \mathrm{abAB}$ & $37.5 \mathrm{bBC}$ \\
TAM02 & $41.6 \mathrm{aA}$ & $41.9 \mathrm{aA}$ & $43.0 \mathrm{aA}$ & $33.3 \mathrm{bcB}$ & $33.4 \mathrm{bB}$ & $37.5 \mathrm{abB}$ & $36.0 \mathrm{bB}$ \\
TAM03 & $42.9 \mathrm{aA}$ & $31.1 \mathrm{cB}$ & $41.1 \mathrm{aA}$ & $40.2 \mathrm{abA}$ & $39.5 \mathrm{abA}$ & $41.4 \mathrm{abA}$ & $38.1 \mathrm{bAB}$ \\
Tc & $40.1 \mathrm{aAB}$ & $36.9 \mathrm{bcB}$ & $43.6 \mathrm{aA}$ & $42.1 \mathrm{aAB}$ & $42.8 \mathrm{aA}$ & $34.4 \mathrm{bB}$ & $41.8 \mathrm{abAB}$ \\
Tce & \multicolumn{7}{c}{$\mathrm{CV}(\%) 15.8$} \\
\hline
\end{tabular}

$\mathrm{CV}$ : coefficient of variation. Means followed by the same lowercase letters in the columns and by the same uppercase letters in the rows do not differ by Tukey's test $(p<0.01)$. TAM01: Trichoderma asperellum; TAM02: Trichoderma asperellum; TAM03: Trichoderma asperellum; Tc: Trichoderma sp.; Tce: Trichoderma sp.; TS: seed treatment; AS: application on the preplanting substrate; and AQ: biweekly applications in postplanting soil.

In the biweekly applications on the postplanting substrate, there was no difference between the Trichoderma isolates tested, except for T. asperellum-TAM02, which caused the lowest height of the seedlings. The only mode of application that did not provide the lowest values in this variable was its use in the seed treatment (Table 4).

The analysis of the interaction between the factors for the variable collar diameter showed a similar result to the one found for the height of the plant, comparing the seed treatment with the different Trichoderma isolates. In this treatment, the fungus T. asperellum-TAM01 also resulted in the smallest diameter of the seedlings collection. There was no difference between the other fungal isolates (Table 5).

Table 5. Average collar diameter of Açaí (Euterpe oleracea) plants submitted to different modes of application of five isolates of Trichoderma spp. at 132 days after planting.

\begin{tabular}{cccccccc}
\hline \multirow{2}{*}{$\begin{array}{c}\text { Trichoderma } \\
\text { Isolates }\end{array}$} & \multicolumn{7}{c}{ Average Collar Diameter (cm) } \\
\cline { 2 - 7 } & TS & AS & AQ & TS + AS & TS + AQ & AS + AQ & TS + AS + AQ \\
\cline { 2 - 7 } & $6.1 \mathrm{bC}$ & $6.8 \mathrm{aB}$ & $7.2 \mathrm{aAB}$ & $6.7 \mathrm{abBC}$ & $6.9 \mathrm{aAB}$ & $6.7 \mathrm{aBC}$ & $7.5 \mathrm{aA}$ \\
TAM01 & $7.0 \mathrm{aA}$ & $6.3 \mathrm{bcBC}$ & $6.3 \mathrm{bBC}$ & $5.7 \mathrm{cCD}$ & $7.1 \mathrm{aA}$ & $6.7 \mathrm{aAB}$ & $5.6 \mathrm{cD}$ \\
TAM02 & $6.5 \mathrm{aBC}$ & $7.0 \mathrm{aB}$ & $7.0 \mathrm{aB}$ & $6.1 \mathrm{bcCD}$ & $5.7 \mathrm{bD}$ & $6.9 \mathrm{aB}$ & $7.6 \mathrm{aA}$ \\
TAM03 & $6.8 \mathrm{aA}$ & $6.9 \mathrm{aA}$ & $7.0 \mathrm{aA}$ & $6.9 \mathrm{aA}$ & $7.1 \mathrm{aA}$ & $6.8 \mathrm{aA}$ & $7.2 \mathrm{abA}$ \\
Tc & $7.1 \mathrm{aA}$ & $6.1 \mathrm{cC}$ & $6.8 \mathrm{abAB}$ & $7.0 \mathrm{aA}$ & $6.9 \mathrm{aAB}$ & $6.3 \mathrm{aBC}$ & $6.8 \mathrm{abAB}$ \\
Tce & \multicolumn{7}{c}{$\mathrm{CV}(\%) 7.3$} \\
\hline
\end{tabular}

$\mathrm{CV}$ : coefficient of variation. Means followed by the same lowercase letters in the columns and by the same uppercase letters in the rows do not differ by Tukey's test $(p<0.01)$. TAM01: Trichoderma asperellum; TAM02: Trichoderma asperellum; TAM03: Trichoderma asperellum; Tc: Trichoderma sp.; Tce: Trichoderma sp.; and TS: seed treatment. AS: application on the preplanting substrate. AQ: biweekly applications in postplanting soil.

It was observed that in four of the seven modes of application of Trichoderma tested, T. asperellum-TAM02 was one of the fungi that caused the smallest collar diameters of seedlings, and in the combination of seed + preplanting substrate + postplanting biweekly applications in substrate, only this isolate differed from the others. There was no difference between the fungi in the mode of application on the substrate when considering planting combined with biweekly applications in the postplanting soil (Table 5).

In relation to the leaf area of the açaí seedlings in the interaction between the factors, a difference was observed between the treatments when only the Trichoderma isolates were applied in the seeds, in the preplanting substrate, and in the biweekly applications separately. There was no difference in this variable in the four combinations of the modes of application evaluated for any of the fungi (Table 6). 
Table 6. Average leaf area of Euterpe oleracea plants submitted to different modes of application of five Trichoderma spp isolates at 132 days after planting.

\begin{tabular}{cccccccc}
\hline \multirow{2}{*}{$\begin{array}{c}\text { Trichoderma } \\
\text { isolates }\end{array}$} & \multicolumn{7}{c}{ Average Leaf Area $\left(\mathbf{c m}^{\mathbf{2}}\right)$} \\
\cline { 2 - 8 } & TS & AS & AQ & TS + AS & TS + AQ & AS + AQ & TS + AS + AQ \\
\cline { 2 - 7 } & $107.9 \mathrm{abAB}$ & $105.8 \mathrm{aAB}$ & $128.2 \mathrm{abA}$ & $104.5 \mathrm{aAB}$ & $123.8 \mathrm{aAB}$ & $112.6 \mathrm{aAB}$ & $96.2 \mathrm{aB}$ \\
TAM01 & $83.2 \mathrm{bBCD}$ & $73.7 \mathrm{bCD}$ & $58.6 \mathrm{dD}$ & $95.7 \mathrm{aBC}$ & $96.9 \mathrm{aBC}$ & $114.6 \mathrm{aA}$ & $105.2 \mathrm{aAB}$ \\
TAM02 & $125.4 \mathrm{aA}$ & $105.2 \mathrm{aAB}$ & $103.2 \mathrm{bcAB}$ & $99.2 \mathrm{aAB}$ & $99.0 \mathrm{aAB}$ & $117.8 \mathrm{aAB}$ & $94.1 \mathrm{aB}$ \\
TAM03 & $124.4 \mathrm{aA}$ & $96.0 \mathrm{bBC}$ & $91.5 \mathrm{cBC}$ & $118.1 \mathrm{aAB}$ & $114.1 \mathrm{aAB}$ & $113.1 \mathrm{aAB}$ & $86.0 \mathrm{aC}$ \\
Tc & $117.5 \mathrm{aA}$ & $121.2 \mathrm{aA}$ & $139.9 \mathrm{aA}$ & $114.6 \mathrm{aA}$ & $122.0 \mathrm{aA}$ & $128.7 \mathrm{aA}$ & $112.4 \mathrm{aA}$ \\
Tce & \multicolumn{7}{c}{$\mathrm{CV}(\%) 21.7$} \\
\hline
\end{tabular}

CV: coefficient of variation. Means followed by the same lowercase letters in the columns and by the same uppercase letters in the rows do not differ by Tukey's test $(p<0.01)$. TAM01: Trichoderma asperellum; TAM02: Trichoderma asperellum; TAM03: Trichoderma asperellum; Tc: Trichoderma sp.; Tce: Trichoderma sp.; TS: seed treatment; AS: application on the preplanting substrate; and AQ: biweekly applications in postplanting soil.

For the number of leaves in the isolated interaction of Trichoderma $\times$ modes of application, there was no difference between the application modes for the isolates of T. asperellum-TAM02, T. asperellum-TAM03, and Trichoderma sp.-Tc. However, for the T. asperellum-TAM01 isolate, differences between seed treatment and application on the preplanting substrate were observed, as well as between application to the preplanting substrate and biweekly applications. In two cases, the application to the preplanting substrate resulted in the largest number of leaves.

In relation to the root length with respect to the interaction between the factors, a difference was observed between the application modes only for the isolate T. asperellum-TAM01. For this fungus, there was a difference between the application in the preplanting substrate and the biweekly applications in the postplanting substrate, observing a longer root length in the first mode of application.

In the analysis of factor interaction for aerial part dry mass, no differences were observed between the application modes for the isolates T. asperellum-TAM02 and Trichoderma sp.-Tce, nor among the four modes of applications in combined use for T. asperellum-TAM01. There was a difference between the seed treatment and the seed treatment combination + application to the preplanting substrate when the T. asperellum-TAM03 isolate was used, observing a higher dry mass of the aerial part in the seed application.

A difference was also observed between the modes of application for Trichoderma sp.-Tc. The treatment of seeds and the combination of seeds and biweekly applications differed from biweekly and triple application treatments (seeds + substrate + biweekly applications), causing greater increases in dry mass of aerial part than these samples and not differing from other treatments.

In the dry mass of the root, there was no difference between the application modes for the isolates of Trichoderma spp., except for T. asperellum-TAM01. For this isolate, the highest values in the analyzed variable were observed when applied to the preplanting substrate, in the treatment of seeds + biweekly applications, and in the application to the preplanting substrate + fortnightly applications.

\section{Discussion}

The biostimulant use is an important practice in sustainable agriculture. In this study, we tested treatments using Trichoderma, a fungus occurring in agricultural and natural soils. We used five isolates from different regions of the Amazonia, combined with seven forms of application in açaí seeds. In our results, in all treatments, germination was almost total. However, only the isolate TAM03 increased germination compared to the control (Table 1), showing that the other fungi did not influence this variable. According to Nascimento [21], seeds of mature açaí fruits sown immediately after the pulp removal have germination higher than $90 \%$.

Cadore et al. [22] verified an increase in germination of rice cultivar IRGA 424 R1 using an industrial

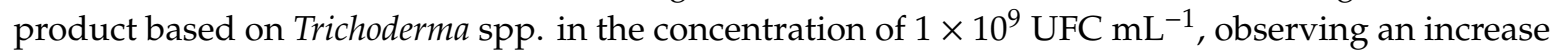


of $7.15 \%$. Silva et al. [23] evaluated the effects of the commercial product Ecotrich ${ }^{\circledR}$ WP based on T. harzianum in the treatment of soybean seeds and concluded that the fungus inoculation in the seeds demonstrates that the biological control agent is able to colonize seeds and roots of soy seedlings. However, it was not able to promote the emergence of seedlings under the conditions of the study.

The contrary effect was observed by Bernardes et al. [24], that used the same Trichoderma isolates, in Dalbergia spruceana seeds, observing that T. asperellum-TAM01 reduced the germination of this plant species by $18 \%$ in relation to the control treatment.

None of the Trichoderma isolates increased the SG in relation to the control. A similar result was found by Machado et al. [25], who also did not observe a significant difference for this variable in Gochnatia polymorpha (Cambará) seeds treated with different Trichoderma isolates on non-sterilized substrates. The rate of germination may be related to the morphological and physiological characteristics of the seed itself [26], and according to Machado et al. [25], the promotion of germination is a specific mechanism and that some Trichoderma isolates may promote, inhibit, or not alter the germination process. Santos et al. [27] evaluated three of the same isolates used in this work (T. asperellum-TAM01, T. asperellum-TAM02, and T. asperellum-TAM03) in Theobroma grandiflorum seeds and also did not observe significant difference for germination and SG.

In the nursery experiment, 12 treatments increased the height of açaí seedlings in relation to the control. The effect of Trichoderma on this variable was also reported by Machado et al. [25] who applied Trichoderma isolates to the sterilized substrate seven days before sowing and observed an increase in the height of G. polymorpha. Resende et al. [28] did not observe a significant difference in height of maize plants inoculated with $T$. harzianum 45 days after sowing.

Although nutrient solubilization and hormone production by Trichoderma isolates tested in this work have not been evaluated, fungi of this genus are reported to act as nutrient solubilizers and growth hormone producers, such as the IAA that is related with cell division and stretching. This result probably provided leaf expansion and consequently increased the photosynthetic area and the growth of açaí seedlings treated with these fungi.

Gravel et al. [29] found a correlation between the production of indole-3-acetic acid (IAA) by a Trichoderma sp. with the growth of tomato plants inoculated with the fungus. The IAA is the main auxin in the higher plants because it is more abundant and physiologically more important, acting on the cellular elongation, growth, and root branching, consequently increasing the soil exploration area, which results in greater growth promotion [30]. In addition to the production of hormones or other growth factors, some fungi may also have the ability to solubilize important plant nutrients and, consequently, provide an increase in the vegetative growth of the species [31].

Trichoderma isolates increased the collar diameter of açaí palm seedling in $85.3 \%$ of tested treatments. The collar diameter is considered by many researchers as one of the most important parameters to estimate the survival of seedlings of forest species in the field, and the pattern of many forest species suitable for planting has a high correlation with this variable, which can be verified in significant increases in survival rates and plant growth in the field [32].

In addition, the diameter of the seedlings is a good variable to be evaluated when the quality of the seedlings is of interest, as opposed to the height that may indicate the planting of nonrustic seedlings. This parameter can cause an increase in the mortality in the field, because the height is strongly influenced by environmental variations [33]. Our results showed that isolates were efficient to benefit these two important variables for the decision when to take the seedlings to the field.

According to Gomes et al. [34] and Lima et al. [35], seedlings planted in adverse conditions must present a quality standard that allows for their survival, favors their growth and establishment, results in shorter transplanting time, reduces replanting costs, and gives a higher yield. França [36] used different Trichoderma isolates to promote the initial development of cherry tomatoes and found similar results to that observed in this work for the leaf area index of this horticulture. According to Rudek et al. [33], the determination of the leaf area, associated with the diameter of the seedlings, is a consistent tool to determine the quality of the seedlings of Eucalyptus grandis. 
Only one isolate of Trichoderma (TAM01 applied to preplanting substrate + biweekly to substrate) did influence on leaf number of açaí palm seedling. Gava and Menezes [37] did not find a significant difference by the Dunnett's test for leaf area of yellow melon plants treated with $10^{8}$ conidia $\mathrm{mL}^{-1}$ suspension of different Trichoderma isolates via seeds, considering there was no reduction of this variable in relation to control.

Regarding the root size (Table 3), the use of T. asperellum-TAM01 isolate applied to preplanting substrate and biweekly to substrate caused the highest mean for this variable. Root size is an important variable because it allows the plant to have a greater capacity to absorb available nutrients in the soil and thus develop better.

The effect of Trichoderma on root development has been reported by other authors, such as Bernardes et al. [24], who worked with the same Trichoderma isolates and observed different results for D. spruceana, and all isolates differed significantly in relation to the control treatment, noting that the T. asperellum-TAM02 isolate caused an increase of $1.81 \mathrm{~cm}$ in the root length. In cupuaçu seeds, T. asperellum-TAM02 and T. asperellum-TAM03 isolates also promoted the increase of root length in relation to the control treatment [27], and by Patekoski and Pires-Zottarelli [38], who evaluated the product Trichodel Hydroponics at concentrations of $0.25,0.5$, and $1 \mathrm{~mL} \mathrm{~L}^{-1}$, and the authors did not observe growth promotion of lettuce varieties Vera and Elisa between treatments with and without application of the product. However, in the presence of the pathogen Pythium aphanidermatum at 20 and $31^{\circ} \mathrm{C}$, the application of the Trichodel in the three concentrations significantly increased the root length of the varieties, indicating the effectiveness of the product in the control of P. aphanidermatum.

The application of Trichoderma in substrate can be an important practice in the development of plants. In this sense, we tested different types of applications. Jesus et al. [39] studied the T. asperellum species incorporated to the substrate for the development and promotion of coffee crop growth (Coffea arabica L.) and found a significant difference in relation to control values for leaf area, total dry mass, as well as increased efficiency of phosphorus absorption.

The root dry mass and aerial part dry mass of açaí palm seedling were influenced by few combinations of Trichoderma isolates and types of application (Table 3). Carvalho Filho et al. [40] obtained superior results in relation to the dry mass of the control seedlings of a Eucalyptos-G100 hybrid, treated with different Trichoderma isolates via substrate and applied every 30 days for a period of two months.

Cadore et al. [22] found no difference in the dry mass of the aerial part of the cultivar IRGA 424 R1 that received application of Trichoderma spp. and the control treatment, and Milanesi et al. [41] also did not observe influence of the application of Trichoderma on the dry mass and the plant root length.

Azevedo et al. [42] evaluated the development and quality of clonal seedlings of Eucalyptus camaldulensis (clone 58) inoculated with T. harzianum and Trichoderma virens by different methods (treatment of mini cuttings, incorporation of colonized rice grains to the substrate, spraying of spore suspension, and the addition of spore suspension to the substrate + spore suspension spray). The authors observed that the use of Trichoderma provided better performance for all variables analyzed, reporting the largest increases in leaf number (110\%) and aerial part (70.4\%), root (54.7\%), and total dry masses $(64.8 \%)$, as well as Dickson quality index $(70.4 \%)$ with respect to the control treatment. They concluded that these fungi promoted seedling development.

Although not evaluated in this work, some species of Trichoderma have the ability to produce and stimulate phytohormone production in plants. Taiz and Zeiger [30] explained the negative effect on root growth may be related to high concentrations of auxins that stimulate growth of the coleoptiles, strongly inhibiting the root growth.

The lack of uniformity of the responses of the variables for the evaluated treatments may be related to the variability between the lines of Trichoderma spp. with respect to the biochemical and physiological properties, as well as the ecological and environmental adaptability. Thus, these could influence its performance as a promoter or inhibitor of plant growth [43,44]. The activity of the growth promoting agents varies according to the environment in which they are found, such as substrate, 
nutrient availability, and the influence of other microorganisms present in the substrate [25]. According to Benítez et al. [45], the mechanisms of action are often unpredictable, being influenced by the genetic variability of Trichoderma strains, as well as within the same species.

The influence of a particular biocontrol agent depends on the interaction between the fungus and the culture used, and the action and effect of these fungi depends on the physicochemical conditions in which they are found [45].

The result for the root length variable indicates that Trichoderma isolates could be used in any of the application modes except T. asperellum-TAM01. Junges et al. [46] reported significant results for root length in Parapiptadenia rigida (angico) plants planted on a substrate treated with Trichoderma spp. at 20 days before planting. However, for the other species studied, none of the treatments differed from the control.

The potential of T. asperellum as a biocontrol agent and in the promotion of plant growth was evidenced by Silva [47], who inferred that several factors still have to be considered for the effective use of this fungus to be reached for this purpose.

One of the factors that can influence the effect of Trichoderma on plants is the concentration. Sousa et al. [48] evaluated the influence of high doses of T. harzianum on tomato and verified that the seedlings resulting from the treatments with this fungus required a longer time to emerge in relation to the control. In addition, among the verified phytotechnical characteristics, the control treatment remained higher in the area and root dry mass and total dry mass evaluations, as well as in relation to the number of leaves, height, and diameter of the stem.

França et al. [49] aimed at developing an effective method of applying Trichoderma spp. to control the burning of the sheath in rice under flood conditions and showed that the application of T. asperellum isolates (T06, TAM01, TAM02, and TAM03, separately and the four isolates combined) in the treatment of seeds and leaf spraying were efficient in reducing the severity of the disease, as well as increasing the productivity and the weight of the grains. The authors also inferred that the use of Trichoderma as a plant growth promoter could play an important role for the sustainable production of rice in Amazonia, promoting increases in yield and reducing the contamination of rivers, which sustain the floodplains used for domestic and large-scale production.

Regardless of its use as a biological control agent or as a biostimulant, it is vitally important to adjust the applied doses of Trichoderma for each species depending on the conditions of each crop [15].

In the literature, there are numerous other studies evaluating fungi of the genus Trichoderma as a biocontrol agent of diseases, as promoter of growth of agricultural, or forest species, presenting promising results $[25,50-58]$. The results for E. oleracea found in this work show that Trichoderma can contribute to the growth of plants of this palm tree, allowing that sustainable practices can be adopted in the preparation of seedlings of this species.

\section{Conclusions}

Only one Trichoderma isolate increased the germination of açaí. However, although the other fungi do not provide an increase in this variable, the result can still be considered positive, since there was no deleterious effect on the seeds.

Height and collar diameter were the two variables most benefited by isolates and its forms of application. The application modes of the different Trichoderma isolates positively influenced the height, collar diameter, and leaf area of the açaí seedlings. The biweekly application of Trichoderma isolates to the postplanting substrate may provide better behavior in these variables.

The application of the Trichoderma isolate TAM01 on the preplanting substrate + biweekly applications on the postplanting substrate was the combination that most positively influenced the development of açai seedlings.

Future researches are needed to investigate the use of Trichoderma on the physiology of açaí seedlings and their production costs, especially under field conditions or plantation. From this new 
information, it will be possible to define the best treatments and variables to be observed for this species, for future decision making by the açaí producer.

Author Contributions: Conceptualization, D.C.L. and T.A.V.; methodology, All authors; software, D.C.L., T.A.V. and C.A.F.; validation, D.C.L., C.A.F. and T.A.V.; formal analysis, all authors; investigation, all authors; resources, D.C.L., T.A.V. and C.A.F; data curation, all authors; writing—original draft preparation, B.F.C., A.J.C.A., T.A.V. and D.C.L.; writing-review and editing, D.C.L., T.A.V. and C.A.F.; visualization, D.C.L. and T.A.V..; supervision, D.C.L. and T.A.V.; project administration, D.C.L.; funding acquisition, T.A.V. All authors have read and agree to the published version of the manuscript.

Funding: This work was supported by the Institutional Scientific Initiation Scholarship Program2015 PIBIC/UFOPA.

Acknowledgments: We would like to thank the anonymous reviewers for their suggestions and constructive comments on the manuscript.

Conflicts of Interest: The authors declare no conflict of interest.

\section{References}

1. Lorenzi, H.; Souza, H.M.; Costa, J.T.M.; Cerqueira, L.S.C.; van Behr, N. Palmeiras No Brasil: Nativas e Exóticas, 1st ed.; Plantarum: Nova Odessa, Brasil, 1996.

2. Coelho, J.J.V. Forest Economies: A Remedy to Amazonian Deforestation? Indiana Univ. J. Res. 2016, 2, 63-71.

3. Martinot, J.F.; Pereira, H.D.S.; Silva, S.C.P. Coletar ou Cultivar: As escolhas dos produtores de açaí-da-mata (Euterpe precatoria) do Amazonas. Rev. Econ. Sociol. Rural. 2017, 55, 751-766. [CrossRef]

4. Conab-Companhia Nacional de Abastecimento. Conjuntura Mensal: Açaí. Setembro 2016; Conab: Brasília, Brazil, 2016.

5. Tagore, M.P.B.; Canto, O.; Sobrinho, M.V. Políticas públicas e riscos ambientais em áreas de várzea na Amazônia: o caso do PRONAF para produção do açaí. Desenvolv. Meio Ambient. 2018, 45, 194-214. [CrossRef]

6. Brandão, B.B.; Costa, S.J.; Numes, D.P.; Marinho, G.A.; Erasmo, E.A.L. Seletividade de herbicidas no crescimento inicial da cultura do açaí (Euterpe oleraceae Mart.). J. Biotechnol. Biodivers. 2014, 5, 95-100. [CrossRef]

7. Oliveira, M.S.P.; Carvalho, J.E.U.; Nascimento, W.M.O. Açaí (Euterpe oleracea Mart.); Funep: Jaboticabal, Brazil, 2000.

8. Nascimento, W.M.O.; Silva, W.R. Comportamento fisiológico de sementes de açaí (Euterpe oleracea Mart.) submetidas à desidratação. Rev. Bras. Frutic. 2005, 27, 349-351. [CrossRef]

9. Contreras-Cornejo, H.A.; Macías-Rodríguez, L.; Cortés-Penagos, C.; López-Bucio, J. Trichoderma virens, a plant beneficial fungus, enhances biomass production and promotes lateral root growth through an auxin-dependent mechanism in Arabidopsis. Plant Physiol. 2009, 149, 1579-1592. [CrossRef]

10. Silva, C.F.B.; Oliveira, L.L.B.; Sousa, A.B.O.; Rebouças, J.R.L. Uso do Trichoderma na cultura do melão (479-492). In Trichoderma - Uso na Agricultura; Meyer, M.C., Mazaro, S.M., Silva, J.C., Eds.; Embrapa: Brasília, Brazil, 2019; 538p.

11. Harman, G.E.; Petzoldt, R.; Comis, A.; Chen, J. Interactions between Trichoderma harzianum Strain T22 and maize inbred line Mo17 and effects of these interactions on diseases caused by Pythium ultimum and Colletotrichum graminicola. Phytopathology 2004, 94, 146-153. [CrossRef]

12. Mastouri, F.; Björkman, T.; Harman, G.E. Seed Treatment with Trichoderma harzianum Alleviates Biotic, Abiotic, and Physiological Stresses in Germinating Seeds and Seedlings. Phytopathology 2010, 100, 1213-1221. [CrossRef]

13. Machado, D.F.M.; Parzianello, F.R.; Silva, A.C.F.; Antoniolli, Z.I. Trichoderma no Brasil: o fungo e o bioagente. Rev. Ciências Agrárias 2012, 35, 274-288.

14. Santos, G.R.; Ferreira, W.X.; Oliveira, T.M.; Machado, R.C.L.; Silva, G.B. Indução de crescimento em mudas de açaizeiro com o fungo Trichoderma asperrellum. In Ciência, Tecnologia e Desenvolvimento Rural: Compartilhando conhecimentos inovadores e experiências. Intl. J. Edu. Teach 2018. [CrossRef]

15. Monte, E.; Bettiol, W.; Hermosa, R. Trichoderma e seus mecanismos de ação para o controle de doenças de plantas. In Trichoderma - Uso na Agricultura; Meyer, M.C., Mazaro, S.M., Silva, J.C., Eds.; Embrapa: Brasília, Brazil, 2019; 538p. 
16. Alvares, C.A.; Stape, J.L.; Sentelhas, P.C.; Gonçalves, J.L.M.; Sparovek, G. Köppen's climate classification map for Brazil. Meteorol. Z. 2013, 22, 711-728. [CrossRef]

17. Martins, C.C.; Nakagawa, J.; Bovi, M.L.A. Desiccation tolerance of four seedlots of Euterpe edulis Mart. Seed Sci. Tech. 2000, 28, 1-13.

18. Maguire, J.D. Speed of germination-aid in selection and evaluation for seedling emergence and vigor. Crop. Sci. 1962, 2, 176-177. [CrossRef]

19. Alfenas, C.A.; Mafia, R.G. Métodos em Fitopatologia; UFV: Viçosa, Brazil, 2007.

20. Silva, F.A.S. Assistat: Versão 7.7 Beta; DEAG-CTRN-UFCG: João Pessoa, 2014; Available online: http: //www.assistat.com (accessed on 20 May 2014).

21. Nascimento, W.M.O. Açaí (Euterpe Oleracea Mart.); Rede de Sementes da Amazônia: Manaus, Brazil, 2008.

22. Cadore, L.S.; Silva, N.G.; Vey, R.T.; Silva, A.C.F. Inoculação de sementes com Trichoderma harzianum e Azospirillum brasiliense no desenvolvimento inicial de arroz. Enciclopédia Biosfera 2016, 13, 1725-1731. [CrossRef]

23. Silva, F.F.; Castro, E.M.; Moreira, S.I.; Ferreira, T.C.; Lima, A.E.; Alves, E. Emergência e análise ultraestrutural de plântulas de soja inoculadas com Sclerotinia sclerotiorum sob efeito da aplicação de Trichoderma harzianum. Summa Phytopathol. 2017, 43, 41-45. [CrossRef]

24. Bernardes, V.P.; Andrade, D.S.; Lustosa, D.C.; Vieira, T.A.; Rayol, B.P.; Silva, G.B. Avaliação de isolados de Trichoderma na germinação de sementes de jacarandá-do-pará (Dalbergia spruceana). In $44^{\circ}$ Congresso Brasileiro de Fitopatologia; Annals of XLIV Congresso Brasileiro de Fitopatologia: Bento Gonçalves, Brazil, 2011.

25. Machado, D.F.M.; Tavares, A.P.; Lopes, S.J.; Silva, A.C.F. Trichoderma spp. na emergência e crescimento de mudas de cambará (Gochnatia polymorpha (Less.) Cabrera). Revista Árvore 2015, 39, 167-176. [CrossRef]

26. Popinigs, F. Fisiologia de Sementes, 2nd ed.; AGIPLAN: Brasília, Brazil, 1985.

27. Santos, M.F.; Costa, D.L.; Matos, J.C.N.; Silva, G.B.; Vieira, T.A.; Lustosa, D.C. Tratamento biológico de sementes de cupuaçu para o controle de fitopatógenos e promoção da germinação. Cadernos de Agroecologia 2018, 13, 1 .

28. Resende, M.L.; Oliveira, J.A.; Guimarães, R.M.; Von Pinho, R.G.; Vieira, A.R. Inoculação de sementes de milho utilizando o Trichoderma harzianum como promotor de crescimento. Ciência e Agrotecnologia 2004, 28, 793-798. [CrossRef]

29. Gravel, V.; Antoun, H.; Tweddell, R.J. Growth stimulation and fruit yield improvement of greenhouse tomato plants by inoculation with Pseudomonas putida or Trichoderma atroviride: Possible role of indole acetic acid (IAA). Soil Biol. Biochem. 2007, 39, 1968-1977. [CrossRef]

30. Taiz, L.; Zeiger, E. Fisiologia Vegetal, 5th ed.; Artmed: Porto Alegre, Brazil, 2013.

31. Hoyos-Carvajal, L.; Orduz, S.; Bissett, J. Growth stimulation in bean (Phaseolus vulgaris L.) by Trichoderma. Biol. Control. 2009, 51, 409-416. [CrossRef]

32. Gomes, J.M.; Paiva, H.N. Viveiros Florestais-Propagação Sexuada, 3rd ed.; Editora UFV: Viçosa, Brazil, 2004.

33. Rudek, A.; Garcia, F.A.O.; Bandeira, F.S.P. Avalição da qualidade de mudas de Eucalipto pela mensuração da área foliar com o uso de imagens digitais. Enciclopédia Biosfera 2013, 9, 3776.

34. Gomes, J.M.; Couto, L.; Leite, H.G.; Xavier, A.; Garcia, S.L.R. Parâmetros morfológicos na avaliação de qualidade de mudas de Eucalyptus grandis. Revista Árvore 2002, 26, 655-664. [CrossRef]

35. Lima, J.D.; Silva, B.M.S.; Moraes, W.S.; Dantas, V.A.V.; Almeida, C.C. Efeitos da luminosidade no crescimento de mudas de Caesalpinia ferrea Mart. Ex Tul. (Leguminosae, Caesalpinoideae). Acta Amaz. 2008, 38, 5-10. [CrossRef]

36. França, D.V.C. Interação de Isolados de Trichoderma spp. e Preparados Homeopáticos: Estudo In Vitro e No Desenvolvimento Inicial do Tomateiro-Cereja. Master's Thesis, Universidade Federal de São Carlos, São Carlos, Brazil, 2016.

37. Gava, C.; Menezes, M.E.L. Eficiência de isolados de Trichoderma spp no controle de patógenos de solo em meloeiro amarelo. Revista Ciência Agrônomica 2012, 43, 633-640. [CrossRef]

38. Patekoski, K.D.S.; Pires-Zottarelli, C.L.A. Efeito de Trichoderma spp no controle de podridão de raiz causada por Pythium aphanidermatum e na promoção de crescimento de alface hidropônica. Acta Sci. Biol. Res. 2016, 1, 59-74. [CrossRef]

39. Jesus, E.P.; Souza, C.H.E.; Pomella, A.W.V.; Costa, R.L.C.; Seixas, L.; Silva, R.B. Avaliação do potencial de Trichoderma asperellum como condicionador de substrato para a produção de mudas de café. Cerrado Agrociências 2011, 2, 7-19. 
40. Carvalho Filho, M.R.; Mello, S.C.M.; Santos, R.P.; Menêzes, J.E. Avaliação de Isolados de Trichoderma na Promoção de Crescimento, Produção de ácido Indolacético In Vitro e Colonização Endofítica de Mudas de Eucalipto; Embrapa Recursos Genéticos e Biotecnologia: Brasília, Brazil, 2008.

41. Milanesi, P.M.; Blume, E.; Antonioli, Z.I.; Muniz, M.F.B.; Santos, R.F.; Finger, G.; Durigon, M.R. Biocontrole de Fusarium spp. com Trichoderma spp. e promoção de crescimento em plântulas de soja. Rev. Ciências Agrárias 2013, 36, 347-356.

42. Azevedo, G.B.; Novaes, Q.S.; Azevedo, G.T.O.S.; Silva, H.F.; Sobrinho, G.G.R.; Novaes, A.B. Efeito de Trichoderma spp. no crescimento de mudas clonais de Eucalyptus camaldulensis. Sci. For. 2017, 45, 343-352. [CrossRef]

43. Junges, E.; Manzoni, C.G.; Milanesi, P.; Brand, S.C.; Durigon, M.R.; Blume, E.; Muniz, M.F.B. Germinação e vigor de sementes de arroz semeadas em substrato tratado com o bioprotetor Trichoderma spp em formulação líquida ou pó. Cadernos de Agroecologia 2007, 2, 2.

44. Silva, V.N.; Guzzo, S.D.; Lucon, C.M.M.; Harakava, R. Promoção de crescimento e indução de resistência à antracnose por Trichoderma spp. em pepineiro. Pesquisa Agropecuária Brasileira 2011, 46, 1609-1618. [CrossRef]

45. Benítez, T.; Rincón, A.M.; Limón, M.C.; Codón, A.C. Biocontrol mechanisms of Trichoderma strains. Int. Microbiol. 2004, 7, 149-260.

46. Junges, E.; Muniz, M.F.; Mezzomo, R.; Bastos, B.; Machado, R.T. Trichoderma spp. na produção de mudas de espécies florestais. Floresta Ambient. 2016, 23, 237-244. [CrossRef]

47. Silva, B.D.S. Ação Antimicrobiana de Enzimas Hidrolíticas Produzidas por Trichoderma asperellum e Imobilizadas em Blendas de Polímeros Biodegradáveis. Master's Thesis, Universidade Federal de Goiás, São Carlos, Brazil, 2011.

48. Souza, E.P.; Amaral, H.F.; Santos Neto, J.; Nunes, M.P. Alta dosagem de Trichoderma harzianum em tomateiro influencia negativamente a produção de mudas e produção. Revista Terra Cultura 2018, 34, 20-36.

49. De França, S.K.S.; Cardoso, A.F.; Lustosa, D.C.; Ramos, E.M.L.S.; De Filippi, M.C.C.; Silva, G.B. Biocontrol of sheath blight by Trichoderma asperellum in tropical lowland rice. Agro. Sustain. Dev. 2014, 35, 317-324. [CrossRef]

50. Bortolin, G.S.; Wiethan, M.M.S.; Vey, R.T.; Oliveira, J.C.P.; Köpp, M.M.; Silva, A.C.F. Trichoderma na promoção do desenvolvimento de plantas de Paspalum regnellii Mez. Rev. Ciências Agrárias 2019, 42, 135-145. [CrossRef]

51. Carvalho Filho, M.R.; Martins, I.; Peixoto, G.H.S.; Muniz, P.H.P.; Carvalho, D.D.C.; Mello, S.C. Biological control of leaf spot and growth promotion of Eucalyptus plants by Trichoderma spp. J. Agric. Sci. 2018, 10, 459-467. [CrossRef]

52. Soldan, A.; Watzlawick, L.F.; Botelho, R.V.; Faria, C.M.D.R.; Maia, A.J. Development of forestry species inoculated with Trichoderma spp. fertilized with rock phosphate. Floresta Ambient. 2018, 25, e20160643. [CrossRef]

53. Amaral, P.P.; Steffen, G.P.K.; Maldaner, J.; Missio, E.L.; Saldanha, C.W. Promotores de crescimento na propagação de caroba. Pesq. Flor. Bras. 2017, 37, 149-157. [CrossRef]

54. Santos, M.F.; Costa, D.L.; Vieira, T.A.; Lustosa, D.C. Effect of Trichoderma spp. fungus for production of seedlings in Enterolobium Schomburgkii (Benth.) Benth. Aust. J. Crop. Sci. 2019, 13, 1706-1711. [CrossRef]

55. Lustosa, D.C.; Araújo, A.J.C.; Campo, B.F.; Vieira, T.A. Trichoderma spp. and its effects on the physiological quality of seeds and development of seedlings of African mahogany. Rev. Bras. Cienc. Agrar. 2020, 15. [CrossRef]

56. Rosmana, A.; Taufik, M.; Asman, A.; Jayanti, N.J.; Hakkar, A.A. Dynamic of Vascular Streak Dieback Disease Incidence on Susceptible Cacao Treated with Composted Plant Residues and Trichoderma asperellum in Field. Agronomy 2019, 9, 650. [CrossRef]

57. Santos, M.F.; Santos, L.E.; Costa, D.L.; Vieira, T.A.; Lustosa, D.C. Trichoderma spp. on treatment of Handroanthus serratifolius seeds: Effect on seedling germination and development. Heliyon 2020, 6. [CrossRef] [PubMed]

58. Larkin, R.P.; Brewer, M.T. Effects of Crop Rotation and Biocontrol Amendments on Rhizoctonia Disease of Potato and Soil Microbial Communities. Agriculture 2020, 10, 128. [CrossRef]

(C) 2020 by the authors. Licensee MDPI, Basel, Switzerland. This article is an open access article distributed under the terms and conditions of the Creative Commons Attribution (CC BY) license (http://creativecommons.org/licenses/by/4.0/). 